\title{
CHEMICAL COMPOSITION OF SWINE WASTEWATER, SOIL, AND TIFTON 85 AFTER 8 YEARS OF APPLICATION ${ }^{1}$
}

\author{
JAQUELINE ROCHA WOBETO SARTO ${ }^{2 *}$, MARCELA ABBADO NERES ${ }^{2}$, SAMANTHA MARIANA MONTEIRO \\ SUNAHARA ${ }^{2}$, CAROLINE DAIANE NATH ${ }^{2}$, MARCOS VINICIUS MANSANO SARTO ${ }^{3}$
}

\begin{abstract}
The aim of this study was to evaluate the chemical composition of swine wastewater (SW), and its effect on the chemical attributes of soil and plants in a long-term experiment. The area was designed for an 8 -year hay production, using Tifton 85 grass (Cynodon spp.), with an average annual application of $360 \mathrm{~m}^{3} \mathrm{ha}^{-1}$, divided into 6 applications. Also, soil chemical composition was evaluated at $0.0-0.20$ and $0.20-0.40 \mathrm{~m}$ of depth, and the chemical composition of plant and vegetable materials on the ground were evaluated for two months (November and June). Concentrations of N, Ca, and $\mathrm{Cu}$ in SW did not decrease from the affluent to the storage lagoon. It was observed that the content of $\mathrm{Cu}, \mathrm{Zn}$, and $\mathrm{Mn}$ was classified as in excess in soil that could be a consequence of high levels of these micronutrients utilized in rations of swine in the SW supplier farm, mainly in the rations of piglets combined with a low extraction of these nutrients by plants. In relation to micronutrients and $\mathrm{P}\left(46.08 \mathrm{mg} \mathrm{dm}^{-3}\right)$ in the soil, these should be evaluated in greater depth than performed in the present study, because the concentrations did not vary considerably among depths and were high. The concentrations of $\mathrm{Cu}$ and $\mathrm{Zn}$ were high in shoot plants with an average of 133.0 and $139.30 \mathrm{mg} \mathrm{kg}^{-1}$, respectively. The continuous use of SW should be monitored continuously through analyses of soil and waste, and alternatives must be researched to reduce the concentration of micronutrients and $\mathrm{P}$ in $\mathrm{SW}$.
\end{abstract}

Keywords: Affluent. Biodigester. Cynodon spp. Manure. Swine fertilizer.

\section{COMPOSIÇÃo QUÍMICA DA ÁGUA RESIDUÁRIA DA SUINOCULTURA, DO SOLO E TIFTON 85 APÓS 8 ANOS DE APLICAÇÃO}

RESUMO - O objetivo deste trabalho foi avaliar a composição química da água residuária da suinocultura (ARS) e efeito nos atributos químicos do solo e planta em um experimento de longa duração. A área destina-se a 8 anos a produção de feno de capim Tifton 85 (Cynodon spp.), com aplicação média anual de $360 \mathrm{~m}^{3} \mathrm{ha}^{-1}$ dividida em 6 aplicações. Também se avaliou a composição química do solo em duas profundidades $0,0-0,20 \mathrm{e}$ 0,20-0,40 m de profundidade e a composição química da planta e material vegetal sobre o solo, avaliada em duas épocas do ano (novembro e junho). As concentrações de nitrogênio, cálcio e cobre da ARS não reduziram do afluente até a lagoa de armazenamento. Ressalta-se que os teores de $\mathrm{Cu}, \mathrm{Zn}$ e $\mathrm{Mn}$ foram classificados como em excesso no solo, que pode ser consequência dos elevados níveis destes nutrientes na ração dos suínos na granja fornecedora da ARS, principalmente na ração de leitões aliado a baixa extração destes nutrientes pelas plantas. Com relação aos micronutrientes e o fósforo $\left(46,08 \mathrm{mg} \mathrm{dm}^{-3}\right)$ no solo estes deverão ser avaliados em profundidades maiores, superiores ao presente estudo em função das concentrações não variarem muito entre profundidades e se mostrarem elevadas. As concentrações de cobre e zinco foram elevadas na parte aérea das plantas com médias de 133,0 e 139,30 mg kg-1, respectivamente. O uso contínuo de ARS deverá ter monitoramento contínuo através de análises de solo e do dejeto e alternativas devem ser buscadas no sentido de reduzir a concentração de micronutrientes e fósforo na ARS.

Palavras-chave: Afluente. Biodigestor. Biofertilizante suíno. Cynodon spp. Esterco.

\footnotetext{
${ }^{*}$ Corresponding author

${ }^{1}$ Received for publication in $07 / 13 / 2017$; accepted in $11 / 27 / 2018$

Paper extracted from the Master's dissertation of the first author.

${ }^{2}$ Department of Animal Science, Universidade Estadual do Oeste do Paraná, Marechal Cândido Rondon, PR, Brazil; jaquelinerwsarto@gmail.com - ORCID: 0000-0002-4944-7159, mabbadoneres@yahoo.com.br - ORCID: 0000-0003-3221-4030, samanthasunahara@yahoo.com.br - ORCID: 0000-0002-8777-6180, karolynedayane@hotmail.com - ORCID: 0000-0002-6996-5201.

${ }^{3}$ Department of Agronomy, Kansas State University, Manhattan, KS, United States of America; marcos.sarto28@gmail.com - ORCID: 0000-0002-7421-1869.
} 


\section{INTRODUCTION}

Brazil generates around 100 million $\mathrm{m}^{3}$ of swine wastewater per year from swine production (SEGANFREDO, 2007). The swine wastewater (SW) is a mixture of urine, feces, orts of ration, potable water, and water that was used to clean installations. The use of anaerobic digesters is a technique that appears to reduce the pollutant load of SW, which allows for effluent storage from livestock and biogas production as well as the use of final effluents as fertilizers (TOPP et al., 2009).

The use of SW as a fertilizer is an alternative to recovery of degraded pasture areas and currently, due to the increase in hay production in some locations, as a function of the increased commercialization activity of hay and not only the use of property (NERES; AMES, 2015), this fertilizer has been utilized in these areas to recover extracted nutrients (SARTO et al., 2018). The use of SW in these areas appears to be an environmental alternative for swine producers who, due to questions of environmental risk, cannot discard this residue in watercourses due to high oxygen demand (OD). Other restrictions in relation to direct disposal in watercourses is due to effluent discharge into sweet waters as a result of the resolution 430/2011 of CONAMA, which limits the use of $\mathrm{Mn}, \mathrm{Zn}$, and $\mathrm{Cu}$; therefore, they cannot exceed 1.0, 5.0, and $1.0 \mathrm{mg} \mathrm{L}^{-1}$, respectively.

In several regions, SW exceeds the amount that can be accommodated safely by available agricultural lands, and repeated annual applications with large amount of liquid swine residue can lead to excessive accumulation of nutrients and lead to environmental damages of the surroundings by nutrient lixiviation (HERNÁNDEZ; POLO; PLAZA, 2013).

The chemical composition of SW can vary from production area (affluent) to application area, and the continuous use in hay production areas needs further study. Even though hay production areas have high nutrient demands, constant applications of SW could compromise groundwater, and as a function of high concentrations of micronutrients, can cause changes in soil chemical composition. Sarto et al. (2018) discovered that the microbial count in the SW was reduced during the treatment process, with higher counts in the affluent, and lower counts in the effluent and storage pond. The SW treatment was efficient in reducing the microbial population. However, few studies have focused on the chemical composition of SW that is utilized to irrigate the area of production of the hybrid bermudagrass, Tifton 85 .
Thus, our aim was to characterize the chemical composition of SW in a production area (swine production) after passing through a Canadian model digester (effluent), and after exiting the digester and storage lagoon close to the hay production field. Also, the concentrations of macronutrients and micronutrients were evaluated at two soil depths in Tifton 85 (Cynodon spp.) grass hay production areas that periodically receive swine fertilizer from a digester during two seasons, and the effects of the composition of vegetable tissue and vegetable material on soil were also evaluated.

\section{MATERIAL AND METHODS}

The experiment was carried out in the field conditions using a property designed for hay production in Marechal Cândido Rondon, PR, Brazil, with a total area of 20 ha, geographical coordinates are $24^{\circ} 33^{\prime} 40^{\prime}$ ' S, $54^{\circ} 04^{\prime} 12^{\prime}$ ' $\mathrm{W}$, with an elevation of $420 \mathrm{~m}$. According to Köppen, the type of climate in the region was $\mathrm{Cfa}$, which is described as a subtropical with well distributed rains over the year and hot summers. The climatic conditions at the collection stations are described in Figure 1. The soil was classified as Rhodic Acrudox (SOIL SURVEY STAFF, 2010), with $377 \mathrm{~g} \mathrm{~kg}^{-1}$ clay, the chemical and physical attributes analyzed according to Embrapa (2009), are presented in Table 1.

The area was planted with Tifton 85 grass for eight years and is exclusively used to produce hay and haylage and the only fertilizer source used is SW. SW was processed by anaerobic digestion, where by it was treated in a continuous flow biodigester Canadian model, with a capacity of 3,200 $\mathrm{m}^{3}$ and 45 day of hydraulic retention time. The effluent was carried to a storage pond that was covered with a black plastic blanket and had a capacity of $2,475 \mathrm{~m}^{3}$.

The SW pig farm was characterized as a confined unit to produce breeding pigs, which had pig barn, and approximately 3,600 animals, including lactating sows, pregnant pigs, and piglets. The unit had pig barn that were categorized as nursery, maternity, and pregnancy rooms. The piglets remained in the farm until they reached approximately the age of 30 days. SW from several pig barn (affluent), was carried to the biodigester via concrete side channels and the facilities were cleaned daily. Upon leaving biodigester, the produced SW was conveyed to the effluent tank and pumped into the storage pond with a capacity of $900 \mathrm{~m}^{3}$, which was located in the hay and haylage production area. 
Rainfall $(\mathrm{mm}) \quad \longrightarrow \mathrm{T} \operatorname{Max}\left({ }^{\circ} \mathrm{C}\right) \quad \cdots \mathrm{UR}(\%)$

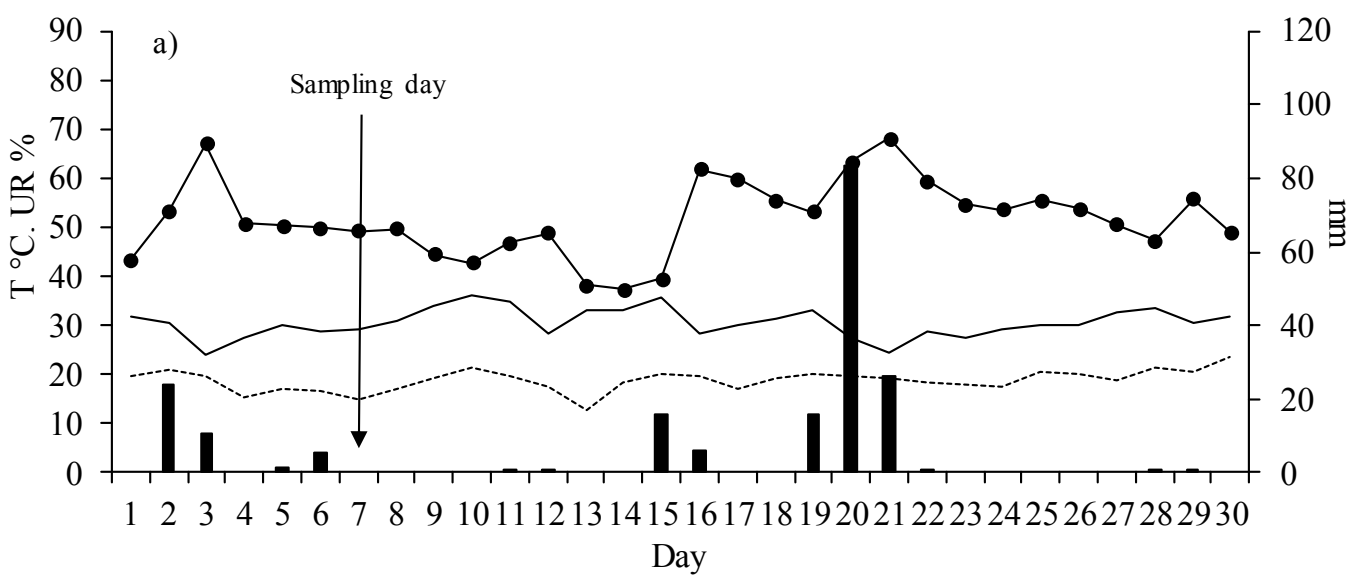

Rainfall $(\mathrm{mm}) \quad \longrightarrow \mathrm{T} \operatorname{Max}\left({ }^{\circ} \mathrm{C}\right) \quad \cdots-\cdot-\cdot-\mathrm{T}$ Mín $\left({ }^{\circ} \mathrm{C}\right) \quad \longrightarrow \mathrm{UR}(\%)$

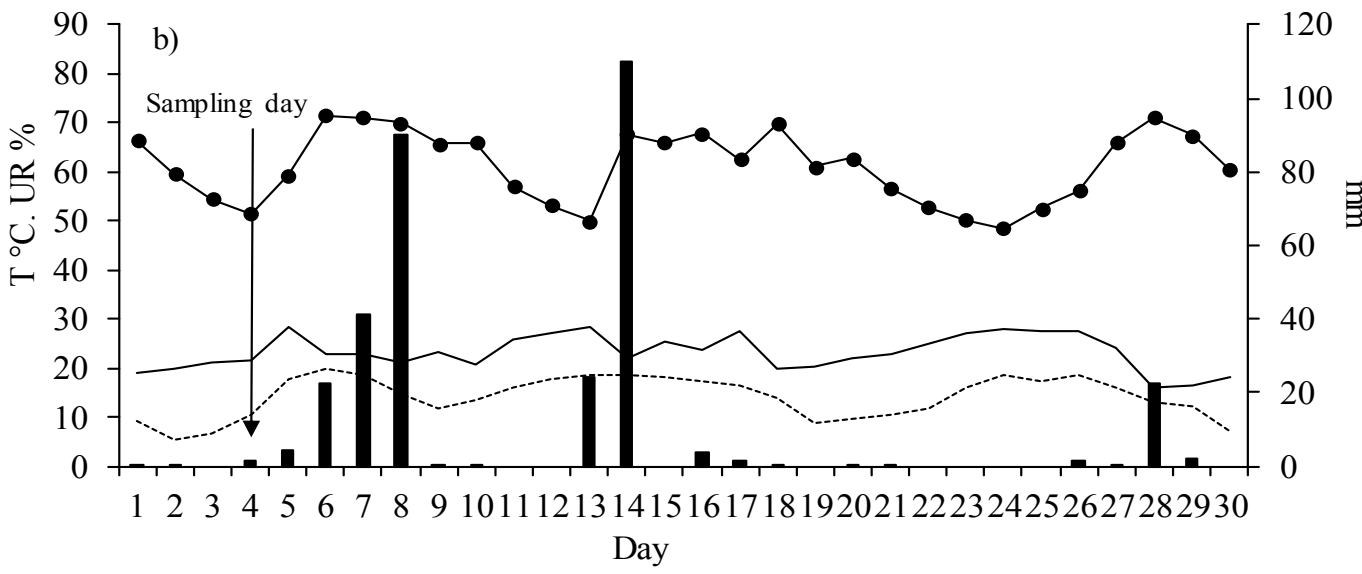

Figure 1. Precipitation, maximum and minimum temperatures and relative humidity during rainy season (November, a) and dry season (June, b) in Marechal Cândido Rondon, Paraná, Brazil.

Table 1. Chemical and granulometric attributes of soil collected at a depth of $0-0.2 \mathrm{~m}$ in the year 2007 .

\begin{tabular}{|c|c|c|c|c|c|c|c|c|c|c|}
\hline $\mathrm{pH}$ & $\mathrm{V}$ & $\mathrm{P}$ & $\mathrm{OM}$ & $\mathrm{Ca}^{2+}$ & $\mathrm{Mg}^{2+}$ & $\mathrm{K}^{+}$ & $\mathrm{Al}^{3+}$ & $\mathrm{H}+\mathrm{Al}$ & SB & CEC \\
\hline $\mathrm{CaCl}_{2}$ & $\%$ & $\mathrm{mg} \mathrm{dm}{ }^{-3}$ & $\mathrm{~g} \mathrm{dm}^{-3}$ & \multicolumn{7}{|c|}{$\mathrm{cmol}_{\mathrm{c}} \mathrm{dm}^{-3}$} \\
\hline 4.55 & 50 & 16.91 & 20.51 & 3.74 & 0.62 & 0.06 & 0.2 & 4.4 & 4.42 & 8.82 \\
\hline $\mathrm{Cu}$ & & $\mathrm{Zn}$ & & $\mathrm{Fe}$ & & $\mathrm{Mn}$ & & Clay & Silt & Sand \\
\hline \multicolumn{7}{|c|}{$-\mathrm{mg} \mathrm{dm}{ }^{-3}-$} & & \multicolumn{3}{|c|}{$\mathrm{g} \mathrm{kg}^{-1}$} \\
\hline 9.9 & & 15.1 & & 5.9 & & 3.5 & & 377.0 & 499.3 & 123.7 \\
\hline
\end{tabular}

Mehlich-1 extractor: $\mathrm{P}, \mathrm{K}$, micronutrients; $\mathrm{KCl}$ extractor $1 \mathrm{~mol} \mathrm{~L}^{-1}$ : $\mathrm{Al}, \mathrm{Ca}, \mathrm{Mg}$; $\mathrm{pH} \mathrm{SMP}$ (7.5): $\mathrm{H}+\mathrm{Al} ; \mathrm{CaCl}_{2}$ extractor: pH (EMBRAPA, 2013).

Pumping was done once or twice a week, according to the amount of SW produced and the need for hay and haylage production. The area has been wastewater-irrigated since 2007 is about 20 ha. SW was sprayed on the surface area of hay and haylage production using a hose-reel irrigation machine with hydraulic controls applied to rotation, after 7 and 14 days of forage regrowth, at an average of $60 \mathrm{~m}^{3} \mathrm{ha}^{-1}$ per application, with an average of 6 annual cuts and an average annual production of $16,000 \mathrm{~kg}$ of dry matter $(\mathrm{DM})^{-1}$ commercialized as hay. The rate of SW was established based on the recommendation of organic fertilization of the Chemistry and Soil Fertility (CQFS) - RS/SC (2004), which considers that $80 \%$ of total $\mathrm{N}$ present in SW will be available to the crop after the application of the wastes, about $200 \mathrm{~kg} \mathrm{~N}^{-1}$ year $^{-1}$ was applied to the surface soil, divided into 6 applications per year. 
Before application, SW was homogenized with their own equipment coupled to a tractor to perform the decantation process. The chemical analysis of SW by flame atomic absorption spectrometry (FAAS) revealed the following composition: $0.80 \mathrm{~g} \mathrm{~kg}^{-1}$ of $\mathrm{N}, 0.96 \mathrm{~g} \mathrm{~L}^{-1}$ of $\mathrm{K}, 4.62 \mathrm{~g}$
$\mathrm{L}^{-1}$ of $\mathrm{P}, 0.64 \mathrm{~g} \mathrm{~L}^{-1}$ of $\mathrm{Ca}, 0.03 \mathrm{~g} \mathrm{~L}^{-1}$ of $\mathrm{Mg}, 0.87 \mathrm{mg}$ $\mathrm{L}^{-1}$ of $\mathrm{Cu}, 0.45 \mathrm{mg} \mathrm{L}^{-1}$ of $\mathrm{Zn} 0.24 \mathrm{mg} \mathrm{L}^{-1}$ of $\mathrm{Mn}$, and $5.61 \mathrm{mg} \mathrm{L}^{-1}$ of Fe. Density, dry matter, $\mathrm{pH}$, and temperature were obtained for SW at different collection locations (Table 2).

Table 2. Dry matter, density, $\mathrm{pH}$, and temperature of swine wastewater and ambient at the affluent, effluent and storage lagoon in November and June.

\begin{tabular}{|c|c|c|c|c|c|}
\hline \multicolumn{6}{|c|}{ November } \\
\hline Local & $\mathrm{DM}$ & Density & $\mathrm{pH}$ & Temp. (SW) & Temp. (Ambient) \\
\hline & $\%$ & $\mathrm{~g} \mathrm{ml}^{-1}$ & & & 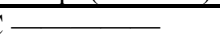 \\
\hline Affluent & 0.46 & 0.94 & 8.20 & 25.4 & 34.0 \\
\hline Effluent & 0.21 & 0.96 & 7.50 & 29.9 & 34.0 \\
\hline Lagoon & 0.21 & 0.93 & 7.40 & 26.7 & 31.3 \\
\hline \multicolumn{6}{|c|}{ June } \\
\hline Local & $\mathrm{DM}$ & Density & $\mathrm{pH}$ & Temp. (SW) & Temp. (Ambient) \\
\hline & $\%$ & $\mathrm{~g} \mathrm{ml}^{-1}$ & \multicolumn{3}{|c|}{${ }^{0} \mathrm{C} \longrightarrow$} \\
\hline Affluent & 0.54 & 0.96 & 8.23 & 12.8 & 21.5 \\
\hline Effluent & 0.27 & 0.96 & 7.84 & 18.6 & 21.0 \\
\hline Lagoon & 0.16 & 0.95 & 8.14 & 15.0 & 18.8 \\
\hline
\end{tabular}

The experimental design was a randomized block design with a split plot. The treatments were collection points of SW (affluent, effluent, storage lagoon: plots) and months (November and June: subplots) with four replications, while depths in soil (0.0-0.20 and 0.20-0.40 cm: plots) and months (November and June; subplots) had five replications. Also, shoots of plants and vegetable material deposited on the ground that were allocated to the main plot and collections were evaluated in November and June (subplots) with five replications.

The collection of samples of waste and soil for chemical analysis was performed during both evaluation seasons and occurred when Tifton 85 grass was close to being cut. Chemical analyses of macronutrients and micronutrients of SW samples as well as shoot and vegetable material deposited on the ground were performed as follows: soil $\mathrm{pH}$ in 0.01 mol $\mathrm{L}^{-1} \mathrm{CaCl}_{2}$ solution was determined potentiometrically in a 1:2.5 (soil:solution) suspension by using a combined calomel reference glass electrode and $\mathrm{pH}$ meter. Organic matter was quantified by oxidation with potassium dichromate in the presence of sulfuric acid (ROSSET et al., 2014; ROSSET et al., 2016), followed by titration with ammonium Fe(II) sulfate (EMBRAPA, 2013). Available phosphorus (P), exchangeable potassium $\left(\mathrm{K}^{+}\right)$, and cationic micronutrients $\left(\mathrm{Cu}^{+}, \mathrm{Zn}^{+}, \mathrm{Fe}^{+}\right.$, and $\mathrm{Mn}^{+}$) were extracted using Mehlich-1 solution in a $1: 10 \quad(\mathrm{w}: \mathrm{v})$ soil-to-extractant solution ratio (EMBRAPA, 2013, SARTO et al., 2011); P was determined using colorimetry at $725 \mathrm{~nm}$ wave length and $\mathrm{K}^{+}$and micronutrients were determined using atomic absorption spectrophotometry. Calcium $\left(\mathrm{Ca}^{2+}\right)$ and magnesium $\left(\mathrm{Mg}^{2+}\right)$ were extracted by 1 mol $\mathrm{L}^{-1} \mathrm{KCl}$ solution and determined using atomic absorption spectrophotometry. Cation exchange capacity (CEC) was estimated using the summation method $\left(\mathrm{CEC}=\mathrm{H}+\mathrm{Al}^{+}+\mathrm{Ca}^{2+}+\mathrm{Mg}^{2+}+\mathrm{K}^{+}\right)$. Plant
$\mathrm{P}$ by sulfuric digestion was read in ultraviolet-visible spectrophotometry (UV-vis), the content of $\mathrm{Ca}, \mathrm{Mg}$, $\mathrm{K}, \mathrm{Cu}, \mathrm{Zn}, \mathrm{Mn}$, and $\mathrm{Fe}$ by nitro-perchloric acid digestion (AOAC, 1990) was quantified by flame atomic absorption spectrophotometry (WELZ, 1985), and $\mathrm{N}$ by the Kjeldahl method.

Samples for chemical analyses of soil, at depths of $0.0-0.20 \mathrm{~m}$ and $0.20-0.40 \mathrm{~m}$, were dried in a forced-ventilation oven at $65^{\circ} \mathrm{C}$ for 48 hours; after which it was characterized as dried soil in an oven (DSO), and was sieved in a $2 \mathrm{~mm}$ screen according to the methodology from Paraná Agronomy Institute (PAVAN et al., 1992).

In relation to statistical procedures, as the experiment was using repeated measures, the sphericity test was used as in the initial step and was used to verify (MAUCHLY, 1940) whether a multivariate population presents with equal variances and null correlations and if so, we need to determine whether the error covariance matrix denoted by $\sum$ meets the condition of HUYNH-FELDT (H-F): a condition that is adequate to determine whether the $\mathrm{F}$ test of the usual variance analysis, in a split plot scheme, is valid (XAVIER, 2000). The sphericity test for repeated measures proceeded by utilizing multivariate variance analysis from the GLM procedure of Statistical Analyses System (SAS, 2000) for each dependent variable that was evaluated.

After this step, univariate variance analysis for repeated measures was performed while aiming to verify the effects of treatments, time, and interaction between treatments and time on variables. Data were submitted to variance analysis by the SISVAR program (FERREIRA, 2011) at 5\% of significance. When significant differences were detected among treatments, the means were compared by Tukey test, at significance levels of $5 \%$. 


\section{RESULTS AND DISCUSSION}

\section{Swine wastewater composition}

$\mathrm{N}$ did not differ among collection locations in November and June, which were on average 0.73 and $0.90 \mathrm{~g} \mathrm{~kg}^{-1}$ (Table 3). Around $2 / 3 \mathrm{~N}$ present in SW presents as ammonium $\left(\mathrm{NH}^{4+}\right)$, and the remainder as organic form (SCHERER, 2002); which can produce losses by volatilization depending on application conditions. Barros et al. (2005) obtained $2 \mathrm{~g} \mathrm{~L}^{-1}$ of total $\mathrm{N}$ for SW. The same authors verified that at a temperature of $25^{\circ} \mathrm{C}$, microorganisms performed greater nitrification, and therefore, conversion of ammonia into nitrate.
Batista et al. (2014), when utilizing SW in the fertilization of eucalyptus seedlings, obtained variations in total $\mathrm{N}$ content from 0.40 to $0.50 \mathrm{~g} \mathrm{~L}^{-1}$.

There was an interaction between collection locations and months in terms of content of $\mathrm{P}, \mathrm{K}$, and $\mathrm{Zn}$ (Table 3 ). $\mathrm{P}$ content was greater in affluent in relation to effluent and storage lagoon, with a reduction of $5.1 \mathrm{~g} \mathrm{~L}^{-1}$ from affluent to effluent in June and $46 \%$ in November, thereby showing that this element can settle; this is evidence of the importance of SW homogenization when it comes to avoiding greater losses in $\mathrm{P}$ deficient soils. In November, the $\mathrm{P}$ concentration was higher in relation to June.

Table 3. Composition of macro and micronutrients of swine wastewater from the production area to the application area in November and June.

\begin{tabular}{|c|c|c|c|c|c|c|c|c|}
\hline \multirow[b]{3}{*}{ Treatment } & \multicolumn{2}{|c|}{$\mathrm{N}$} & \multirow[b]{3}{*}{ Nov. } & & \multicolumn{2}{|c|}{ K } & \multicolumn{2}{|c|}{$\mathrm{Zn}$} \\
\hline & \multicolumn{2}{|c|}{$-\mathrm{g} \mathrm{kg}^{-1}$} & & $g$ & & \multirow[b]{2}{*}{ June } & \multicolumn{2}{|c|}{$-\mathrm{mg} \mathrm{L}^{-1}-$} \\
\hline & Nov. & June & & June & Nov. & & Nov. & June \\
\hline Affluent & 0.70 & 1.00 & $19.85 \mathrm{aA}$ & $6.84 \mathrm{aB}$ & $0.51 \mathrm{aB}$ & $0.99 \mathrm{aA}$ & $14.95 \mathrm{aA}$ & $4.35 \mathrm{aB}$ \\
\hline Effluent & 0.80 & 0.90 & $9.05 \mathrm{bA}$ & $1.74 \mathrm{bB}$ & $0.62 \mathrm{aA}$ & $0.54 \mathrm{bA}$ & $0.76 \mathrm{bA}$ & $0.24 \mathrm{bA}$ \\
\hline Lagoon & 0.70 & 0.80 & $8.85 \mathrm{bA}$ & $0.39 \mathrm{bB}$ & $0.68 \mathrm{aB}$ & $1.24 \mathrm{aA}$ & $0.60 \mathrm{bA}$ & $0.30 \mathrm{bA}$ \\
\hline Mean & 0.73 & 0.90 & 12.58 & 4.49 & 0.6 & 0.92 & 5.44 & 1.63 \\
\hline CV (\%) & \multicolumn{2}{|c|}{9} & \multicolumn{2}{|c|}{14} & \multicolumn{2}{|c|}{20} & \multicolumn{2}{|c|}{24} \\
\hline $\mathrm{CV}(\%)$ & \multicolumn{2}{|c|}{6} & \multicolumn{2}{|c|}{20} & \multicolumn{2}{|c|}{19} & \multicolumn{2}{|c|}{55} \\
\hline
\end{tabular}

Means followed of the same lowercase letter and means followed of the same uppercase letter did not differ among them by Tukey test at level of $5 \%$.

Vivan et al. (2010), when studying the performance of a system of manure treatment, composed of a digester and stabilization lagoons, also found a reduction in $\mathrm{P}$ content in SW during the production process. This process occurs mainly by physico-chemical removal through $\mathrm{P}$ precipitation as calcium phosphate because of the high concentration of $\mathrm{Ca}$ in manure (STEINMETZ, 2007).

In November, $\mathrm{K}$ content did not vary among collection locations, but in June, there was a decrease in effluent and after, an increase in storage lagoon (Table 3). The concentrations were greater in the affluent in June, they did not differ in effluent, and they were greater in the lagoon in June. Barros et al. (2005) obtained $\mathrm{K}$ content of $0.062 \mathrm{~g} \mathrm{~L}^{-1}$ in SW. K is found freely and is readily available after the application (PAULETTI; MOTTA, 2004).

$\mathrm{Zn}$ content decreased in effluent and storage lagoon during both months that were evaluated, and were greater in affluent only in November (Table 3 ). Gonçalves et al. (2006) evaluated the quality of SW in irrigated coffee and observed a large variation in manure composition and SW; such as the elements $\mathrm{Fe}, \mathrm{Mn}, \mathrm{Cu}$, and $\mathrm{Zn}$, which were in inappropriate concentrations for the irrigation of agricultural crops. $\mathrm{Zn}$ content in affluent showed a high concentration (4.35 mg L $\mathrm{mg}^{-1}$ ), and was above the limits allowed by resolution 430/2011 from CONAMA.

No interaction was verified considering collection locations and months for $\mathrm{Ca}, \mathrm{Mg}, \mathrm{Cu}, \mathrm{Mn}$, and $\mathrm{Fe}$ of SW (Table 4). The Ca content wad on average $0.67 \mathrm{~g} \mathrm{~L}^{-1}$ among locations and presented with a greater concentration in November than in June. The obtained data were lower than that observed by Camargo et al. (2011), who utilized swine wastewater in Tifton 85 grass and obtained $\mathrm{Ca}$ concentration of $5 \mathrm{~g} \mathrm{~L} \mathrm{~L}^{-1}$ without anaerobic fermentation through direct collection of manure. 
Table 4. Composition of macro and micronutrients of swine wastewater from the production area to the application area in November and June.

\begin{tabular}{|c|c|c|c|c|c|}
\hline Treatment & $\mathrm{Ca}$ & $\mathrm{Mg}$ & $\mathrm{Cu}$ & $\begin{array}{c}\mathrm{Mn} \\
-\mathrm{mg} \mathrm{L}^{-1} \\
\end{array}$ & $\mathrm{Fe}$ \\
\hline Affluent & 0.74 & $0.08 \mathrm{a}$ & 2.28 & $1.51 \mathrm{a}$ & $19.4 \mathrm{a}$ \\
\hline Lagoon & 0.64 & $0.03 \mathrm{~b}$ & 0.87 & $0.24 \mathrm{~b}$ & $5.61 \mathrm{~b}$ \\
\hline Mean & 0.67 & 0.05 & 1.60 & 0.65 & 9.76 \\
\hline November & $1.01 \mathrm{a}$ & $0.05 \mathrm{~b}$ & $2.43 \mathrm{a}$ & $0.82 \mathrm{a}$ & 10.46 \\
\hline Mean & 0.67 & 0.055 & 1.6 & 1.055 & 9.76 \\
\hline CV (\%) & 24 & 18 & 78 & 19 & 19 \\
\hline $\mathrm{CV}(\%)$ & 23 & 21 & 62 & 48 & 40 \\
\hline
\end{tabular}

Means followed by the same lowercase letter in the columns did not differ by Tukey test at a level of $5 \%$.

$\mathrm{Mg}$ concentration was greater in affluent, thereby differing from effluent and storage lagoon (Table 4). Among the months that were evaluated, $\mathrm{Mg}$ concentration was greater in June. Cabral et al. (2011), when evaluating SW in soil and elephant grass production, utilized $\mathrm{SW}$ with a concentration that varied from 0.031 to $0.124 \mathrm{~g} \mathrm{~L}^{-1}$. Thus, it was verified that there was a large variability in nutrient concentrations of SW, similar to the observations made by Pauletti and Motta (2004), because nutrient concentrations in SW vary as a function of frequency of washes, ration composition, animal category, and other factors.

$\mathrm{Cu}$ concentration was influenced only by the collection month and was greater in November (Table 4). According to Pauletti and Mota (2004), there is an environmental concern regarding the use of manure, mainly in relation to $\mathrm{P}, \mathrm{Zn}$, and $\mathrm{Cu}$, because these minerals generally occur in $\mathrm{SW}$ in concentrations above those required by these crops, thereby causing an accumulation in soil when these minerals are used in high frequency. In rations offered to suckling piglets in SW producing farms, Fe content was $95.60 \mathrm{mg} \mathrm{kg}^{-1}$; P $66 \mathrm{~g} \mathrm{~kg}^{-1} ; \mathrm{Cu} 200$ $\mathrm{mg} \mathrm{kg}$; and $59.88 \mathrm{mg} \mathrm{kg}^{-1}$ of $\mathrm{Mn}$, and in a ration where the content was considered high due to mineral contents assimilated by swine, the values were 30 to $55 \% \mathrm{~N}, \mathrm{~K}$, and $\mathrm{P} ; 5$ to $30 \% \mathrm{Cu}, \mathrm{Zn}, \mathrm{Fe}$, and 5 to $10 \% \mathrm{Mn}$ : according to Kornegay and Harper (1997).

$\mathrm{Mn}$ concentration was greater in affluent (1.51 mg L $\left.{ }^{-1}\right)$ in comparison to storage lagoon $(0.24$ $\mathrm{mg} \mathrm{L} \mathrm{L}^{-1}$ ), with a reduction of $151 \%$ (Table 4 ). In November, greater values of Mn were observed. Fe content was also greater in affluent $\left(19.4 \mathrm{mg} \mathrm{L}^{-1}\right)$ when compared to effluent $\left(4.31 \mathrm{mg} \mathrm{L}^{-1}\right)$ and lagoon (5.61 $\left.\mathrm{mg} \mathrm{L}^{-1}\right)$. Collection months did not interfere with iron content. According to the ration composition in different categories, it was observed that there were high concentrations of $\mathrm{Fe}, \mathrm{P}, \mathrm{Cu}, \mathrm{Mn}$, and $\mathrm{Zn}$ in rations of piglets when considering that part of these nutrients $\left(50 \mathrm{~g} \mathrm{~kg}^{-1}\right)$ are excreted.

Vivan et al. (2010) also observed a reduction in the content of $\mathrm{Cu}$ and $\mathrm{Zn}$ in $\mathrm{SW}$, and the anaerobic lagoon was responsible in great part for the removal, thus corresponding to $68 \% \mathrm{Cu}$ and $82 \% \mathrm{Zn}$. According to the authors, this fact may probably be due to a reaction among $\mathrm{S}$ reducing species (i.e., $\mathrm{H}_{2} \mathrm{~S}$ ) produced in anaerobic digestion and $\mathrm{Cu}$ and $\mathrm{Zn}$ producing copper sulfide and zinc sulfide, which are highly insoluble as they are precipitated and accumulate in manure.

\section{Soil attributes after 8 years of $\mathrm{SW}$ application}

There was no interaction between the contents of macronutrients and micronutrients as well as $\mathrm{pH}$, organic matter, and CEC of soil among the seasons of evaluation and depth (Tables 5 and 6). The greatest differences were observed among seasons, and there were minor differences among depths.

Soil P content did not differ between depths; however, they presented high values for the two depths (Table 5), with an average of $46.08 \mathrm{mg} \mathrm{dm}^{-3}$, and this value is considered high for most crops (GUARDINI et al., 2012). In relation to the seasons of the year, soil $\mathrm{P}$ concentration was higher in June than in November. This nutrient and others must be evaluated in greater depth. It is suggested that the evaluation should be performed considering the greater depth that is used in the present study, because the concentrations did not vary among depths. According to Raij et al. (1996), the P content was high in pasture, hay, and silage production areas. 
Table 5. Chemical soil characteristics as a function of the application of swine wastewater at two depths in November and June.

\begin{tabular}{|c|c|c|c|c|c|c|c|}
\hline Depth & $\begin{array}{c}\mathrm{P} \\
\mathrm{mg} \mathrm{dm}^{-3} \\
\end{array}$ & $\begin{array}{c}\mathrm{OM} \\
\mathrm{g} \mathrm{dm}^{-3} \\
\end{array}$ & $\begin{array}{c}\mathrm{pH} \\
\mathrm{CaCl}_{2} \\
\end{array}$ & $\mathrm{H}+\mathrm{Al}$ & \multicolumn{2}{|c|}{$-\mathrm{cmol}_{\mathrm{c}} \mathrm{dm}^{-3}$} & $\mathrm{Mg}^{2+}$ \\
\hline $0.0-0.20 \mathrm{~m}$ & 53.02 & 26.25 & 5.16 & 4.21 & 0.12 & 6.39 & 2.19 \\
\hline $0.20-0.40 \mathrm{~m}$ & 39.14 & 28.16 & 5.27 & 4.79 & 0.11 & 6.34 & 1.91 \\
\hline Mean & 46.08 & 27.21 & 5.22 & 4.50 & 0.11 & 6.37 & 2.05 \\
\hline November & $35.36 \mathrm{~b}$ & $29.39 \mathrm{a}$ & $5.30 \mathrm{a}$ & 4.54 & 0.11 & 6.54 & 2.03 \\
\hline June & $56.80 \mathrm{a}$ & $25.02 \mathrm{~b}$ & $5.10 \mathrm{~b}$ & 4.47 & 0.12 & 6.19 & 2.07 \\
\hline Mean & 46.08 & 27.21 & 5.20 & 4.51 & 0.11 & 6.37 & 2.05 \\
\hline CV $(\%)$ & 27 & 20 & 4 & 11 & 42 & 10 & 17 \\
\hline CV (\%) & 20 & 9 & 4 & 18 & 39 & 11 & 22 \\
\hline
\end{tabular}

Means followed by the same lowercase letter in columns did not differ by Tukey test at the level of $5 \%$.

Table 6. Chemical soil characteristics as a function of the application of swine wastewater at two depths in November and June.

\begin{tabular}{|c|c|c|c|c|c|c|}
\hline Depth & $\begin{array}{c}\mathrm{CEC} \\
\mathrm{cmol}_{\mathrm{c}} \mathrm{dm}^{-3}\end{array}$ & $\begin{array}{r}\mathrm{V} \\
-\% \\
\end{array}$ & $\mathrm{Cu}$ & $\mathrm{Zn}$ & ${ }_{3} \mathrm{Mn}$ & $\mathrm{Fe}$ \\
\hline $0.0-0.20 \mathrm{~m}$ & $13.50 \mathrm{a}$ & 64.49 & 28.48 & 33.33 & 206.20 & 19.22 \\
\hline $0.20-0.40 \mathrm{~m}$ & $12.56 \mathrm{~b}$ & 66.48 & 28.48 & 33.41 & 247.20 & 21.41 \\
\hline Mean & 13.03 & 65.49 & 28.48 & 33.37 & 226.70 & 20.31 \\
\hline November & 13.21 & 65.62 & $33.05 \mathrm{a}$ & 33.29 & $274.3 \mathrm{a}$ & 20.10 \\
\hline June & 12.84 & 65.35 & $23.91 \mathrm{~b}$ & 34.45 & $179.1 \mathrm{~b}$ & 20.53 \\
\hline Mean & 13.03 & 65.48 & 28.48 & 33.87 & 226.70 & 20.32 \\
\hline CV (\%) & 3 & 6 & 18 & 17 & 17 & 24 \\
\hline CV $(\%)$ & 9 & 8 & 24 & 14 & 27 & 8 \\
\hline
\end{tabular}

Means followed by the same lowercase letter in columns did not differ by Tukey test at the level of $5 \%$.

Balota et al. (2014), when evaluating longterm changes in soil (15 years), with different levels of SW, observed an increase in the available $P$ up to $119 \mathrm{mg} \mathrm{kg}^{-1}$ with the application of $120 \mathrm{~m}^{3} \mathrm{ha}^{-1}$ year $^{-1}$ in the same studied soil. According to these authors, applications of successive SW increased the available $\mathrm{P}$ for all levels of application, because the addition of $P$ exceeded the removal of crops. Ceretta et al. (2003) observed an increase in the available P content in depths including the layer of $0.20-0.40 \mathrm{~m}$ as a result of the application of SW several times over four consecutive years.

Organic matter contents were on average $27.21 \mathrm{~g} \mathrm{dm}^{-3}$, with a greater amount in November in relation to June (Table 5). Soil K content did not differ and was on average $0.11 \mathrm{cmol}_{\mathrm{c}} \mathrm{dm}^{-3}$. The same occurs with $\mathrm{Ca}$ and $\mathrm{Mg}$ with averages of 6.37 and $2.05 \mathrm{cmol}_{\mathrm{c}} \mathrm{dm}^{-3}$ while maintaining a proportion of 3.08. This correlated with results obtained by Balota et al. (2014), who did not observe changes in the content of $\mathrm{K}, \mathrm{Ca}$, and $\mathrm{Mg}$ with the application of SW in a Rhodic Acrudox.

Soil $\mathrm{Cu}$ content did not vary among depths but did vary among the months as the value in June was $23.91 \mathrm{mg} \mathrm{dm}^{-3}$; which was lower than that of November (Table 6). The content of $\mathrm{Zn}$ and Fe did not vary with depth and season; however, soil Mn content varied among seasons with $274.3 \mathrm{mg} \mathrm{dm}^{-3}$ for November and $179.1 \mathrm{mg} \mathrm{dm}^{-3}$ for June, but variation among depths in the content was not observed. It was observed that the content of $\mathrm{Cu}, \mathrm{Zn}$, and $\mathrm{Mn}$ were at levels that were classified to be in excess in soil (RAIJ et al., 1996), probably due to the application of SW over the eight years of hay production in the area. Also, it is important to highlight that high rates of manure increase the amount of nutrients in soil, which according to Seganfredo (2007), can potentially lead to soil contamination by excessive amounts of nutrients, thereby reaching toxic levels in soil and water.

\section{Chemical composition of shoot and vegetable material deposited on the ground}

There was an interaction between composition of shoots and litter of Tifton 85 grass fertilized with SW in November and June for content of $\mathrm{N}, \mathrm{P}$, and $\mathrm{Mg}$ (Table 7). $\mathrm{N}$ was greater in shoots in relation to litter in June, and the inverse was observed in November. P content was higher in litter for both months that were evaluated; however, they were greater in June. Higher concentrations than those recommended by Werner, Paulino and Cantarella (1996) were obtained during the collection in June, because the limit that was established by the author was $3 \mathrm{~g} \mathrm{~kg}^{-1}$.

There was no interaction between location and season for the content of $\mathrm{K}$ and $\mathrm{Ca}$ (Table 7). $\mathrm{K}$ 
was higher in shoots in June. Zenatti (2011), obtained $\mathrm{K}$ content of 14.21 and $15.10 \mathrm{~g} \mathrm{~kg}^{-1}$ in the first and second cut, respectively for Tifton 85 grass that was fertilized with swine fertilizer when using a dose of $500 \mathrm{~m}^{3} \mathrm{ha}^{-1}$. However, the Ca content was higher in VM in November. Camargo et al. (2011) obtained shoots of Tifton 85 grass with average $\mathrm{Ca}$ concentrations of $13.45 \mathrm{~g} \mathrm{~kg}^{-1}$ with increasing rates of swine manure and the application of $100 \mathrm{~m}^{3} \mathrm{ha}^{-1}$. The same authors obtained the concentrations of 6.65 and $4.38 \mathrm{~g} \mathrm{~kg}^{-1}$ for $\mathrm{K}$ between the first and third cut. Ca content in shoots was $18.98 \mathrm{~g} \mathrm{~kg}^{-1}$, thus differing from VM which presented with $25.51 \mathrm{~g} \mathrm{~kg}^{-1}$.

$\mathrm{Mg}$ content did not differ in November for shoots and litter, while in June it was greater for shoots (Table 7). Werner, Paulino and Cantarella (1996), considered $\mathrm{Mg}$ in vegetable tissue values to range from 1.5 to $4.0 \mathrm{~g} \mathrm{~kg}^{-1}$, and the value that was obtained in June in this study was higher than those that were recommended $\left(5.0 \mathrm{~g} \mathrm{~kg}^{-1}\right)$. Primavesi, Primavesi and Corrêa (2001), obtained Mg content varying from 1.9 to $2.6 \mathrm{~g} \mathrm{~kg}^{-1}$ for shoots of coastcross grass, with applications from 0 to $1000 \mathrm{~kg} \mathrm{ha}^{-1} \mathrm{~N}$.

Table 7. Composition of shoot and vegetable material on the ground (VM) of Tifton 85 grass that was fertilized with swine wastewater in November and June.

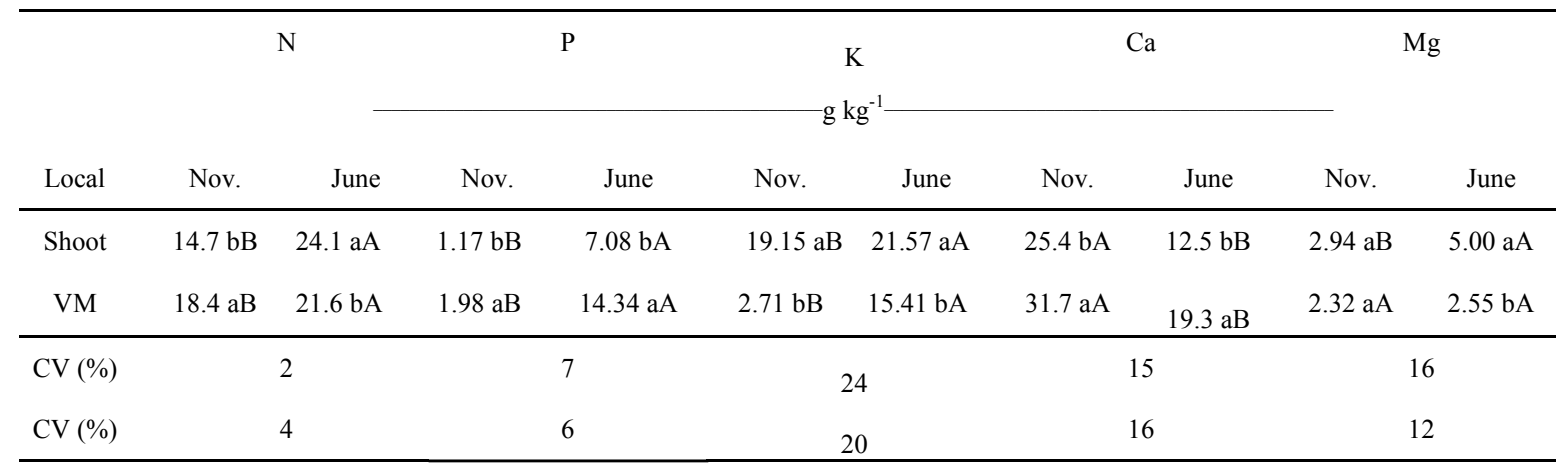

Means followed by the same lowercase letter in columns and means followed by the same uppercase letter in lines did not differ by Tukey test at a level of $5 \%$.

Regarding the micronutrients $(\mathrm{Cu}, \mathrm{Zn}, \mathrm{Fe}$, and $\mathrm{Mn}$ ) of shoots and VM of Tifton 85 grass that was fertilized with swine fertilizer (Table 8), the values for $\mathrm{Cu}, \mathrm{Zn}$, and $\mathrm{Fe}$ were greater for VM. This might be due to successive applications of SW, which can cause an accumulation of these nutrients on the surface of VM that presents as a slow decomposition, mainly in June due to low temperatures (Figure 1).

In the months that were evaluated, there was no difference in the concentration of $\mathrm{Cu}$. However, when shoots were compared to VM with respect to the concentrations, the values were much greater for VM (Table 8). Zn concentration was greater in shoots in November, while it was greater in VM in June. When comparing shoots and VM, Zn was greater in VM. Concentrations of $\mathrm{Cu}$ and $\mathrm{Zn}$ were high in shoots of plants, with averages of 133.0 and $139.30 \mathrm{mg} \mathrm{kg}^{-1}$ respectively. The concentrations of $\mathrm{Cu}$ and $\mathrm{Zn}$ were greater than those recommended by Werner, Paulino and Cantarella (1996), thereby showing that this species is a bioaccumulation of $\mathrm{Cu}$ and Zn. Cunha (2009) highlights the importance of monitoring applications of SW, because in an assay with Brachiaria brizantha 'Marandu' with rates from 100 to $600 \mathrm{~m}^{-3} \mathrm{ha}^{-1}$ year, this species also presented with high levels of $\mathrm{Cu}$ and $\mathrm{Zn}$ in the leaves. $\mathrm{Fe}$ content was greater in VM when compared to shoots.

Table 8. Composition of micronutrients of shoot and vegetable material on the ground (VM) of Tifton 85 grass that was fertilized with swine wastewater in November and June.

\begin{tabular}{|c|c|c|c|c|c|c|c|c|}
\hline \multirow[b]{2}{*}{ Local } & \multicolumn{2}{|c|}{$\mathrm{Cu}$} & \multicolumn{2}{|c|}{$\mathrm{Zn}$} & \multicolumn{2}{|c|}{$\mathrm{Fe}$} & \multicolumn{2}{|c|}{$\mathrm{Mn}$} \\
\hline & Nov. & June & Nov. & June & Nov. & June & Nov. & June \\
\hline Shoot & $133 \mathrm{bA}$ & $45.3 \mathrm{bA}$ & $139.3 \mathrm{bA}$ & $107.3 \mathrm{bB}$ & $542.2 \mathrm{bA}$ & $253.0 \mathrm{bB}$ & $95.5 \mathrm{~b}$ & $96.2 \mathrm{~b}$ \\
\hline VM & $277 \mathrm{aA}$ & $340.6 \mathrm{aA}$ & $735.7 \mathrm{aB}$ & $984.4 \mathrm{aA}$ & $861.7 \mathrm{aA}$ & $803.4 \mathrm{aA}$ & $683.5 \mathrm{a}$ & $770.5 \mathrm{a}$ \\
\hline CV (\%) & \multicolumn{2}{|c|}{37} & \multicolumn{2}{|c|}{5} & \multicolumn{2}{|c|}{10} & \multicolumn{2}{|c|}{21} \\
\hline CV (\%) & \multicolumn{2}{|c|}{33} & \multicolumn{2}{|c|}{8} & \multicolumn{2}{|c|}{10} & \multicolumn{2}{|c|}{14} \\
\hline
\end{tabular}

Means followed by the same lowercase letter in columns and means followed by the same uppercase letter in lines did not differ by Tukey test at a level of $5 \%$. 
Mn had a higher concentration in litter (727.0 $\mathrm{mg} \mathrm{kg}^{-1}$ ) in relation to shoots and did not differ among the months (Table 8). The value of $\mathrm{Mn}$ that was found in shoots of $95.87 \mathrm{mg} \mathrm{kg}^{-1}$ was greater than those recommended by Werner, Paulino and Cantarella (1996), where a range from 15 to $70 \mathrm{mg} \mathrm{kg}^{-1}$ was reported. Primavesi, Primavesi and Corrêa (2001) obtained content varying from 61 to $107 \mathrm{~g} \mathrm{~kg}^{-1} \mathrm{Mn}$, with rates from 0 to $1000 \mathrm{~kg} \mathrm{ha}^{-1} \mathrm{~N}$.

Nutrient contents of shoots and litter of Tifton 85 grass were distinct as shoots had greater content of $\mathrm{N}$ and $\mathrm{Mg}$ in June and $\mathrm{K}$ for both months, while vegetable material on the ground had greater content of $\mathrm{P}, \mathrm{Ca}, \mathrm{Cu}, \mathrm{Zn}$, and $\mathrm{Fe}$ than shoots of Tifton 85 grass in areas of constant application of SW.

\section{CONCLUSIONS}

The content of $\mathrm{N}, \mathrm{Ca}$, and $\mathrm{Cu}$ in $\mathrm{SW}$ did not decrease from the affluent to the storage lagoon. The content of $\mathrm{P}$ and $\mathrm{Zn}$ in $\mathrm{SW}$ decreased from the affluent to the storage lagoon. However, their content can vary as a function of collection season, thus showing variation in SW composition as a function of the amount of wash water in installations and other factors.

Concentrations of $\mathrm{Cu}, \mathrm{Zn}$, and $\mathrm{Mn}$ were classified as in excess in soil as a function of the application time with regards to area and composition of SW.

$\mathrm{P}$ and micronutrients concentrations in soil, with the use constant of SW, must be evaluated in greater depth than they were evaluated in this study, because concentrations were classified as in excess in soil.

The concentrations of $\mathrm{Cu}$ and $\mathrm{Zn}$ were high in shoot plants with an average of 133.0 and $139.30 \mathrm{mg}$ $\mathrm{kg}^{-1}$, respectively. The continuous use of SW must be regularly monitored through soil and manure analyses, and alternatives should be researched to reduce the concentration of micronutrients and $\mathrm{P}$ in SW.

\section{ACKOWLEDGMENTS}

To National Counsel of Technological and Scientific Development - CNPq, for the financial support.

\section{REFERENCES}

ASSOCIATION OF OFFICIAL ANALYTICAL CHEMISTS - AOAC. Official methods of analysis. 1990, 15 ed. AOAC, Washington.

BALOTA, E. L. et al. Soil microbial properties after long-term swine slurry application to conventional and no-tillage systems in Brazil. Science of The Total Environment, v. 490, s/n, p. 397-404, 2014.

BARROS, F. M. et al. Características químicas do solo influenciado pela adição de água residuária da suinocultura. Revista Brasileira de Engenharia Agrícola e Ambiental, v. 9, epub., p. 47-51, 2005.

BATISTA, R. O. et al. O efeito da água residuária da suinocultura no desenvolvimento e qualidade de mudas de Eucalyptusurophylla. Ciência Florestal, v. 24, n. 1, p. 127-35, 2014.

CABRAL, J. R. et al. Impacto da água residuária de suinocultura no solo e na produção de capimelefante. Revista Brasileira de engenharia agrícola e Ambiental, v. 15, n. 8, p. 823-831, 2011.

CAMARGO, S. C. et al. Efeito da aplicação de dejetos de suínos na concentração de minerais na parte aérea de capim-tifton 85. Scientia Agraria Paranaensis, v. 10, n. 2, p. 51-62, 2011.

CERETTA, C. A. et al. Características químicas de solo sob aplicação de esterco líquido de suínos em pastagem natural. Pesquisa Agropecuária Brasileira, v. 38, n. 6, p. 729-35, 2003.

COMISSÃO DE QUÍMICA E FERTILIDADE DO $\mathrm{SOLO}-\mathrm{RS} / \mathrm{SC}$ - CQFS - RS/SC. Manual de Adubação e de Calagem para os estados do Rio Grande do Sul e Santa Catarina. 10. ed. Porto Alegre, RS: SBCS-Comissão de Química e Fertilidade do Solo, 2004. 394 p.

CUNHA, J. L. Impacto ambiental em sistema de pastagem sob aplicações de esterco líquido de suínos. 2009. 91 p. Tese (Doutorado). Universidade Federal de Uberlândia, Uberlândia, 2009.

EMPRESA BRASILEIRA DE PESQUISA AGROPECUÁRIA - EMBRAPA. Sistema brasileiro de classificação de solos. 3 . ed. Rio de Janeiro, RJ: EMBRAPA SOLOS, 2013. 353 p.

EMPRESA BRASILEIRA DE PESQUISA AGROPECUÁRIA - EMBRAPA. Manual de análises químicas de solos, plantas e fertilizantes. 2. ed. Brasília, DF: Informação Tecnológica, 2009, $628 \mathrm{p}$.

FERREIRA, D. F. Sisvar: a computer statistical analysis system. Ciência e Agrotecnologia, v. 35, n. 6, p. 1039-1042, 2011.

GONÇALVES, R. A. B. et al. Diagnóstico da aplicação de águas residuárias da suinocultura na cafeicultura irrigada I. qualidade da água residuária. Irriga, v. 11, n. 2, p. 219-29, 2006. 
GUARDINI, R. et al. Phosphorus accumulation and pollution potential in a Hapludult fertilized with pig manure. Revista Brasileira Ciência do Solo, v. 36, n. 4, p. 1333-42, 2012.

HERNÁNDEZ, D.; POLO, A.; PLAZA, C. Longterm effects of pig slurry on barley yield and $\mathrm{N}$ use efficiency under semiarid Mediterranean conditions. European Journal of Agronomy, v. 44, s/n, p. 7886, 2013.

MAUCHLY, J. W. "'Significance Test for Sphericity of a Normal n-Variate Distribution'. The Annals of Mathematical Statistics, v. 11, n. 2, p. 204-20, 1940.

NERES, M. A.; AMES, J. P. Novos Aspectos Relacionados à Produção de Feno no Brasil. Scientia Agraria Paranaensis, v. 14, n. 1, p. 10-17, 2015.

KORNEGAY, E. T.; HARPER, A. F. Environmental nutrition: Nutrient management strategies to reduce nutrient excretion of swine. The Professional Animal Scientist, v. 13, n. 3, p. 99-111, 1997.

PAUletTI, V.; MOTTA, A. C. V. Fontes Alternativas de nutrientes para adubação de pastagens. In: PEDREIRA, C. G. S.; MOURA, J. C.; FARIA, V. P (Eds.). Fertilidade do solo para pastagens produtivas. Piracicaba, SP: Fundação de Estudos Agrários Luiz de Queiroz. 2004. p. 303-316.

PAVAN, M. A. et al. Manual de análise química de solo e controle de qualidade. Instituto Agronômico do Paraná, Londrina, PR: (Circular, 76), $1992.38 \mathrm{p}$.

PRIMAVESI, O.; PRIMAVESI, A. C.; CORRÊA, L. A. Eficiência agronômica de ureia aplicada superficialmente em pastagens de capim Coastcroos. In: ANAIS DA REUNIÃO ANUAL DA SOCIEDADE BRASILEIRA DE ZOOTECNIA, 2001, Piracicaba, Anais... Piracicaba: USP, 2001, p. 213-214.

RAIJ, B. V. et al. Recomendação de adubação e calagem para o Estado de São Paulo. 2. ed. Piracicaba, SP: IAC, 1996. 285 p.

ZENATTI, R. Produtividade e fitodisponibilidade de nutrientes e metais pesados tóxicos $(\mathrm{Cd}, \mathrm{Cr}$ e $\mathrm{Pb})$ na tifton 85 fertilizada com dejetos provenientes da suinocultura. 2011. 90 f. Dissertação (Mestrado). Universidade Estadual do Oeste do Paraná, Marechal Cândido Rondon, PR. 2011.

ROSSET, J. S. et al. Frações químicas e oxidáveis da matéria orgânica do solo sob diferentes sistemas de manejo, em Latossolo Vermelho. Pesquisa
Agropecuária Brasileira, v. 51, n. 9, p. 1529-1538, 2016.

ROSSET, J. S. et al. Carbon stock, chemical and physical properties of soils under management systems with different deployment times in western region of Paraná, Brazil. Semina: Ciências Agrárias, v. 35, n. 6, p. 3053-3072, 2014.

SARTO, M. V. M.; STEINER, F.; LANA, M. do C. Assessment of micronutrient extractants from soils of Paraná, Brazil. Revista Brasileira de Ciência do Solo, v. 35, n. 6, p. 2093-2103, 2011.

SARTO, J. R. W. et al. Microbiota in swine wastewater treatment plant and area of Tifton 85 grass production. Semina: Ciências Agrárias, v. 39, n. 2, p. 797-808, 2018.

SCHERER, E. E. Aproveitamento do esterco de suínos como fertilizante. In: CURSO DE CAPACITAÇ̃̃O EM PRÁTICAS AMBIENTAIS SUSTENTÁVEIS. EMBRAPA- Empresa Brasileira de Pesquisa Agropecuária, Concórdia, SC 2002, p. 91-101.

SEGANFREDO, M. A. Gestão ambiental na suinocultura. Empresa Brasileira de Pesquisa Agropecuária, Brasília-DF, 1. ed. 2007. 302 p.

SOIL SURVEY STAFF. Keys to Soil Taxonomy, 10th ed. USDA-Natural Resources Conservation Service, Washington, DC, 11. ed. 2010.

STEINMETZ, R. L. R. Aplicação de polieletrólitos para a separação de metais em efluentes da suinocultura. 2007. 55 f. Dissertação (Mestrado). Universidade Federal de Santa Maria, Santa Maria, RS. 2007.

TOPP, E. et al. Livestock waste treatment systems for reducing environmental exposure to hazardous enteric pathogens: some considerations. Bioresource Technology, v. 100, n. 22, p. 5395-5398, 2009.

VIVAN, M. et al. Eficiência da interação biodigestor e lagoas de estabilização na remoção de poluentes em dejetos de suínos. Revista Brasileira Engenharia Agrícola e Ambiental, v. 14, n. 3, p. $320-25,2010$

XAVIER, L. H. Modelos univariado e multivariado para análise de medidas repetidas e verificação da acurácia do modelo univariado por meio de simulação. 2000. 91 f. Dissertação (Mestrado em Agronomia) - Escola Superior de Agricultura "Luiz de Queiroz" - ESALQ, Piracicaba, SP, 2000.

WELZ, B. Atomic absorption spectrometry. 2. ed. 
Weinheim, Wiley, 1985. 907 p.

WERNER, J. C.; PAULINO, V. T.; CANTARELLA, H. Forrageiras. In: RAIJ, B. et al. (Eds.). Recomendações de adubação e calagem para o Estado de São Paulo. Instituto Agronômico de Campinas, Campinas, SP. 1996. 